\title{
Noninvasive Fetal Sex Determination by Real-Time PCR and TaqMan Probes
}

\author{
Mohammad Hossein Ahmadi ${ }^{1}$, Naser Amirizadeh ${ }^{1}$, Maryam Rabiee ${ }^{2}$, \\ Fatemeh Rahimi-Sharbaf ${ }^{3}$, Ali Akbar Pourfathollah*4
}

\begin{abstract}
Background: Noninvasive fetal sex determination by analyzing Y chromosome-specific sequences is very useful in the management of cases related to sex-linked genetic diseases. The aim of this study was to establish a non-invasive fetal sex determination test using Real-Time PCR and specific probes.

Methods: The study was a prospective observational cohort study conducted from August 2018 to September 2019. Venous blood samples were collected from 25 Iranian pregnant women at weeks 7 to 25 of gestation. Cell-free DNA (cfDNA) was isolated from the plasma of samples and fetal sex was determined by SRY gene analysis using the Real-Time PCR technique. In the absence of SRY detection, the presence of fetal DNA was investigated using cfDNA treated with BstUI enzyme and PCR for the epigenetic marker RASSF1A.

Results: Of the total samples analyzed, $48 \%$ were male and 52\% female. The RASSF1A assay performed on SRY negative cases also confirmed the presence of cell-free fetal DNA. Genotype results were in full agreement with neonate gender, and the accuracy of noninvasive fetal sex determination was $100 \%$.

Conclusions: Fetal sex determination using the strategy applied in this study is noninvasive and highly accurate and can be exploited in the management of sex-linked genetic diseases.
\end{abstract}

Keywords: Cell-free fetal DNA, Fetal sex determination, Noninvasive prenatal diagnosis, Sex-linked genetic diseases, SRY.

\section{Introduction}

Molecular determination of fetal sex for management of the women at risk of X-linked recessive genetic diseases in the fetus (abnormality in the male fetus) or where there is a risk of diseases associated with ambiguous development of the external genitalia such as Congenital Adrenal Hyperplasia (abnormality in the female fetus) is clinically important $(1,2)$. If it is found that in cases of $\mathrm{X}$-linked genetic diseases, the sex of the fetus is female, subsequent unnecessary invasive diagnostic procedures will be avoided, or in the case of Congenital Adrenal Hyperplasia, timely dexamethasone treatment can be done for the female fetus $(3,4)$.
Traditional methods for preparing fetal DNA such as chorionic villus sampling (CVS) and amniocentesis have a risk of miscarriage (about $1 \%$ ) due to their invasive nature and cannot be performed before 11 weeks $(5,6)$. With the discovery of cffDNA (cell-free fetal DNA) in the late 1990s, many prenatal tests, including sex determination from the fourth to the fifth week of pregnancy onwards, were performed noninvasively (7-9). CffDNA of the primary origin of placental apoptotic syncytiotrophoblasts has a half-life of about 16 minutes and disappears rapidly from the maternal bloodstream after delivery $(10,11)$. It is lower in the early weeks of 
pregnancy and therefore high sensitivity methods should be used to identify it at this period.

Fetal sex determination using cffDNA is one of the cases where the sensitivity and specificity of the method used to identify the Y-chromosome sequence are of high importance. Several sexlinked markers have been used in studies to identify the presence of the $\mathrm{Y}$ chromosome, and one of the most specific and commonly used markers is the SRY gene (a single-copy gene) (12). The existence of the SRY gene in maternal plasma indicates the presence of a male fetus and its absence is assumed to represent a female fetus. Since deficiency of cffDNA may also be the cause of the non-identification of SRY, the main challenge of using Y-chromosome-specific markers in sex determination is when the fetus is predicted to be female (13). In these cases, other markers, including sex-independent epigenetic markers, need to be used to confirm the presence of fetal DNA in maternal plasma. One of these markers is a tumor suppressor gene promoter called RASSF1A, whose different methylation rates in maternal-derived and fetal-derived DNA can help to differentiate between these two and to decide whether or not fetal DNA is present in the sample studied $(14,15)$.

The present study aimed to establish a reliable method with high accuracy for non-invasive fetal sex determination using Real-Time PCR technique, specific probes and employing RASSF1A confirmatory marker to confirm the presence of fetal DNA.

\section{Materials and methods \\ Ethical statement}

The study was approved by the Ethics Committee of High Institute for Research and Education in Transfusion Medicine (Ethical No.: IR.TMI.REC.1396.031).

\section{Type of study, Sample collection, and preparation}

The present project was a prospective observational cohort study. The protocol of this study was approved by the Ethics Committee of the High Institute for Research and Education in Transfusion Medicine, Tehran, Iran, and all volunteers provided written informed consent. Samples were randomly collected between
August 2018 and September 2019 from Iranian pregnant women (gestational age between 7 and 25 weeks) referring to the women's clinic of Mostafa Khomeini and Mohab Yas hospitals in Tehran for the routine ultrasound examination. Twin pregnancies identified by ultrasonography at week 7 (due to the possibility of a vanishing male from a non-identical vanishing twin syndrome and its interference with testing) and individuals with a history of neoplasm (as an intervening factor in RASSF1A methylation) were not included in this study $(13,16,17)$.

Approximately $5 \mathrm{ml}$ of maternal blood was collected in sterile EDTA tubes and transferred within a maximum of 72 hours $(84 \%$ within the first 48 hours and $16 \%$ afterward) to the Blood Group Genotyping Central Lab, Tehran, Iran. The plasma was separated from the erythrocytes and buffy coat in two discrete steps of centrifugation. The tubes were first centrifuged at $2500 \mathrm{~g}$ for 10 minutes and then the upper plasma layer was recentrifuged at $13,000 \mathrm{~g}$ for 10 minutes. The supernatant was aliquoted in sterile microtubes and stored at $-70{ }^{\circ} \mathrm{C}$ before DNA extraction.

\section{CfDNA extraction}

Cell-free fetal DNA (including maternal and fetal DNA) was extracted from $1 \mathrm{ml}$ of maternal plasma using a magnetic bead-based DNA extraction protocol, Kit for DNA isolation from blood plasma (TESTGENE Inc., Ulyanovsk, Russia) according to the manufacturer's instructions. DNA from samples under 14 weeks of gestation in a final volume of $35 \mu 1$ and DNA from samples above 14 weeks of gestation in a final volume of $50 \mu 1$ from elution buffer were eluted, respectively. DNA purity and concentration were also determined using a NanoDrop ${ }^{\mathrm{TM}}$ One Microvolume UV-Vis Spectrophotometer (Thermo Scientific, Waltham, USA). The DNA was immediately used for PCR.

\section{Real-Time PCR analysis}

Duplex Real-Time PCR analysis (for SRY and beta-globin genes or RASSF1A and beta-actin genes) was performed using LightCycler 96 Real-Time PCR System (Roche, Basel, 
Switzerland) and TaqMan chemistry (duallabelled hydrolysis probes).

The sequences of primers and probes published in previous studies were used $(18,19)$. However, for duplex PCR, they were further analyzed by PrimeTime Multiplex Dye Selection Tool and OligoAnalyzer Tool (available online at https://eu.idtdna.com/pages/tools) and Beacon Designer (available online at https://www.premierbiosoft.com/qOligo/Oligo.js $\mathrm{p}$ ?PID=1). The primers and probes were synthesized by Metabion Company (Metabion $\mathrm{GmbH}$, Steinkirchen, Germany). Details of primers and probes are presented in Table 1.

Table 1. Details of the primers and probes of the target genes in this study.

\begin{tabular}{|c|c|c|c|c|}
\hline Target gene & Type/Direction & Sequence and Label (Reporter 5' and 3' Quencher) & $\begin{array}{l}\text { Final } \\
\text { con. } \\
(\mathbf{n M})\end{array}$ & $\begin{array}{c}\text { Product } \\
\text { size } \\
\text { (bp) }\end{array}$ \\
\hline \multirow{3}{*}{$S R Y$} & Primer/Forward & 5'-TGGCGATTAAGTCAAATTCGC-3' & 400 & \multirow{3}{*}{137} \\
\hline & Primer/Reverse & 5'-CCCCCTAGTACCCTGACAATGTATT - 3' & 400 & \\
\hline & Probe & (FAM) 5'-AGCAGTAGAGCAGTCAGGGAGGCAGA-3' (BHQ1) & 200 & \\
\hline \multirow{3}{*}{ Beta-globin } & Primer/Forward & 5'-GTGCACCTGACTCCTGAGGAGA-3' & 400 & \multirow{3}{*}{102} \\
\hline & Primer/Reverse & 5'-CCTTGATACCAACCTGCCCAG-3' & 400 & \\
\hline & Probe & (HEX) 5'-AAGGTGAACGTGGATGAAGTTGGTGG-3' (BHQ1) & 200 & \\
\hline \multirow{3}{*}{ RASSF1A } & Primer/Forward & 5'-AGCCTGAGCTCATTGAGCTG-3' & 400 & \multirow{3}{*}{130} \\
\hline & Primer/Reverse & 5'-ACCAGCTGCCGTGTGG-3' & 400 & \\
\hline & Probe & (FAM) 5'-CCAACGCGCTGCGCAT-3' (BHQ1) & 200 & \\
\hline \multirow{3}{*}{ Beta-actin } & Primer/Forward & 5'-GCGCCGTTCCGAAAGTT-3' & 400 & \multirow{3}{*}{137} \\
\hline & Primer/Reverse & 5'-CGGCGGATCGGCAAA-3' & 400 & \\
\hline & Probe & $(\mathrm{HEX}) 5^{\prime}-\mathrm{ACCGCCGAGACCGCGTC}-3^{\prime}(\mathrm{BHQ} 1)$ & 200 & \\
\hline
\end{tabular}

\section{Reaction Mixture and amplification conditions}

Each duplex reaction was set up in a final volume of $25 \mu \mathrm{l}$ and consisted of $1 \mu \mathrm{l}$ of each primer (Forward and Reverse), $1 \mu 1$ of the probe, $5 \mu 1$ of the template (from samples or controls), $12.5 \mu \mathrm{l}$ of TaqMan PCR Master Mix (PCR BIOSYSTEMS Ltd., London, UK) and $1.5 \mu \mathrm{l}$ of sterile distilled water (DW). PCR conditions consisted of 10 minutes at $95{ }^{\circ} \mathrm{C}$ for initial denaturation followed by 50 cycles of 30 seconds at $95{ }^{\circ} \mathrm{C}$ for denaturation, 30 seconds at $61{ }^{\circ} \mathrm{C}$ for annealing, and 30 seconds at $72{ }^{\circ} \mathrm{C}$ for the extension. PCR conditions were the same for all target genes.

In addition to SRY, the beta-globin gene in each reaction (in duplex mode) was used as an internal control to ensure the presence of total DNA. In each PCR run, the DNA extracted from nonpregnant females and males was used for positive and negative controls of the SRY gene, respectively. For these positive and negative controls, the concentrations of $9.75 \mathrm{pg} / \mathrm{PCR}$ and 625 $\mathrm{pg} / \mathrm{PCR}$ were used, respectively. Blank control (sterile distilled water) was also used in each PCR run to detect contamination during the amplification process.

\section{Confirming the presence of cffDNA in the negative SRY case}

In the absence of SRY amplification, RASSF1A gene amplification was used to confirm the presence of cffDNA and to rule out false-negative results. This gene is hypermethylated in fetal DNA and hypomethylated in maternal DNA. Using BstUI methylation-sensitive enzyme, the maternal DNA can be digested, and if there is fetal DNA, by doing PCR on it, the RASSF1A gene can be identified, 
which will then confirm the presence of cffDNA. To this aim, $30 \mu \mathrm{l}$ of the desired cfDNA sample was incubated for 1 hour at $60{ }^{\circ} \mathrm{C}$ with 10 units of BstUI enzyme (New England Biolabs, Cambridge, UK). Then, with the same volume and temperature conditions of PCR as mentioned in the preceding sections, this treated sample was evaluated for amplification of the two RASSF1A and betaactin genes (in duplex mode). Since beta-actin is both hypomethylated and enzyme-sensitive in both maternal and fetal DNA, it was used as a control for complete digestion.

\section{Interpretation of PCR results}

Each sample was analyzed in triplicate for each of the target genes, and the amplification results were interpreted as positive, negative and invalid. If at least $2 / 3$ of the replicates were amplified, the result was considered positive, and if none of the replicates was amplified, the result was considered negative. If only $1 / 3$ of the replicates were amplified, the test was repeated in triplicate, and if at least $4 / 6$ of the replicates were amplified, the result was considered positive and otherwise invalid. With regard to all the PCR conditions in this study, the maximum acceptable $\mathrm{Ct}$ value for positive cases was set 40 for all selected genes. For the SRY and RASSF1A genes (in the sample after enzyme treatment) a minimum acceptable $\mathrm{Ct}$ value of 30 was considered.

\section{Quantitative PCR assay using an in-house method}

To perform this in-house procedure, the mononuclear white blood cells (MNCs) were isolated from $6 \mathrm{ml}$ of whole blood using Ficoll. These cells were then accurately counted by an automated hematology analyzer, Sysmex XE 5000 (Sysmex Corporation, Kobe, Japan), and 1:10 and 1:100 dilutions were prepared from them using Phosphate-Buffered Saline (PBS) (Table 2). Knowing that there are 1 or 2 copies of each gene in each human diploid cell, such as MNCs (in heterozygous and homozygous conditions, respectively), according to Tables 3 and 4, the MNCs were re-diluted to achieve the desired copy number. Then, the DNA of each dilution was extracted using the CinnaPure DNA Extraction Kit (SinaClon, Tehran, Iran) and mixed in $50 \mathrm{ml}$ of elution buffer. The Real-Time PCR procedure with the same volume values and temperature conditions mentioned in the previous sections was performed separately for each gene with the specified copy number in triplicate conditions. The standard curve for each gene (SRY, RASSF1A, and beta-globin) was plotted using the real-time PCR instruments' software and the values of efficiency, correlation coefficient (R2) and slope were calculated.

\section{Statistical analysis}

The genotype results from cffDNA were compared with the results of ultrasonography and phenotype (gender) of the newborn at birth. Using MedCalc Version 19.1.5 (MedCalc Software, Belgium), parameters related to diagnostic tests including sensitivity, specificity, positive predictive value, negative predictive value and accuracy of the method were calculated.

\section{Results}

\section{Fetal sex determination}

In this study, a total of 25 pregnant women with a mean age of $27.88 \pm 4.39$ years were studied, $12 \%$ of whom were in the first trimester and $88 \%$ in the second trimester. Of these, 12 samples (48\%) were genotyped as male and 13 samples (52\%) were genotyped as female. The results of RASSF1A gene amplification in 13 samples with negative SRY also confirmed the presence of fetal DNA.

By comparing the results of genotype and phenotype (gender at birth), it was found that there was complete concordance between them and thus all results related to diagnostic test parameters were calculated $100 \%$ (details in Table 5).

The mean cycle threshold $(\mathrm{Ct})$ value for the positive SRY (in duplex mode) results of the samples analyzed was 38.13 in the first trimester and 35.98 in the second trimester.

\section{Quantitative PCR using an in-house method}

The results of the quantification of the three SRY, RASSF1A and beta-globin genes are shown in Table 6. The limit of detection (LOD) of the SRY gene was 1.46 copies per 
reaction and for RASSF1A, beta-globin and beta-actin genes, it was 2.95 copies per reaction.
An overview of the steps and results of this study is shown as a flowchart in Figure 1.

Table 2. Number of mono nuclear cells (MNCs) counted by an automated hematology analyzer and copy number of homozygous and heterozygous genes in undiluted and diluted samples.

\begin{tabular}{lccc}
\hline & Undiluted sample & Dilution of sample & $\mathbf{1 : 1 0 0}$ Dilution of sample \\
\hline MNC number (Mean)/ $\boldsymbol{\mu l}$ & 6000 & 600 & 60 \\
\hline $\begin{array}{l}\text { Gene copy number/ } \boldsymbol{\mu l} \\
\text { (in Heterozygous condition) }\end{array}$ & 6000 & 600 & 60 \\
\hline $\begin{array}{l}\text { Gene copy number/ } \boldsymbol{\mu l} \\
\text { (in Homozygous condition) }\end{array}$ & 12000 & 1200 & 120 \\
\hline
\end{tabular}

Table 3. Dilution of mono nuclear cells (MNCs) to obtain the desired copy number of the SRY gene that is heterozygous (one copy per cell) in human MNCs.

\begin{tabular}{|c|c|c|c|c|c|c|c|}
\hline $\begin{array}{c}\text { Sample } \\
\text { (number of } \\
\text { MNCs) }\end{array}$ & 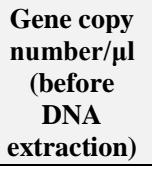 & \begin{tabular}{l}
\multicolumn{1}{c}{ Sample } \\
preparation for \\
DNA extraction \\
Sample volume \\
$(\mu \mathrm{I})+\mathrm{DW}(\mu \mathrm{I})$ \\
\end{tabular} & $\begin{array}{l}\text { Final elution } \\
\text { volume in } \\
\text { DNA } \\
\text { Extraction }(\mu \mathrm{l})\end{array}$ & 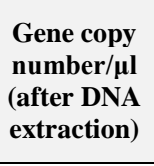 & $\begin{array}{l}\text { Template } \\
\text { volume for } \\
\text { PCR }(\mu \mathrm{l})\end{array}$ & $\begin{array}{c}\text { Final } \\
\text { volume of } \\
\text { PCR } \\
\text { reaction }(\mu \mathrm{I})\end{array}$ & $\begin{array}{c}\text { Final gene copy } \\
\text { number/PCR } \\
\text { reaction }\end{array}$ \\
\hline $\begin{array}{l}\text { 1:10 Dilution } \\
\text { (MNCs: 600) }\end{array}$ & 600 & $83.3+16.7$ & 50 & 1000 & 10 & 25 & 10,000 \\
\hline $\begin{array}{l}\text { 1:10 Dilution } \\
\text { (MNCs: 600) }\end{array}$ & 600 & $8.3+91.7$ & 50 & 100 & 10 & 25 & 1000 \\
\hline $\begin{array}{l}\text { 1:100 Dilution } \\
\text { (MNCs: 60) }\end{array}$ & 60 & $8.3+91.7$ & 50 & 10 & 10 & 25 & 100 \\
\hline $\begin{array}{r}\text { To prepare the } \mathrm{f} \\
\text { from the } \mathrm{s}\end{array}$ & $\begin{array}{l}1 \text { gene copy } \\
\text { ple with the }\end{array}$ & $\begin{array}{l}\text { umber with } 10 \\
0 \text { copies (obtai }\end{array}$ & $\begin{array}{l}\text { pies, we made a } \\
\text { d after DNA ext }\end{array}$ & $\begin{array}{l}10 \text { dilution } \\
\text { ction) }\end{array}$ & 10 & 25 & 10 \\
\hline
\end{tabular}

Table 4. Dilution of mono nuclear cells (MNCs) to obtain desired copy number of the beta-globin and RASSF1A genes that are homozygous (two copies per cell) in human MNCs.

\begin{tabular}{|c|c|c|c|c|c|c|c|}
\hline $\begin{array}{c}\text { Sample } \\
\text { (number of } \\
\text { MNCs) }\end{array}$ & $\begin{array}{c}\text { Gene copy } \\
\text { number/ } \mu \mathrm{l} \\
\text { (before } \\
\text { DNA } \\
\text { extraction) }\end{array}$ & \begin{tabular}{|c|} 
Sample \\
preparation for \\
DNA extraction \\
Sample volume \\
$(\mu \mathrm{l})+\mathrm{DW}(\mu \mathrm{I})$
\end{tabular} & $\begin{array}{l}\text { Final elution } \\
\text { volume in } \\
\text { DNA } \\
\text { Extraction }(\mu \mathrm{l})\end{array}$ & 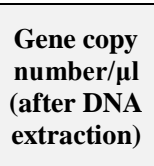 & $\begin{array}{c}\text { Template } \\
\text { volume for } \\
\text { PCR ( } \mu \text { l) }\end{array}$ & $\begin{array}{c}\text { Final } \\
\text { volume of } \\
\text { PCR } \\
\text { reaction } \\
(\mu \mathrm{l})\end{array}$ & $\begin{array}{c}\text { Final gene copy } \\
\text { number/PCR } \\
\text { reaction }\end{array}$ \\
\hline $\begin{array}{l}\text { 1:10 Dilution } \\
\text { (MNCs: 600) }\end{array}$ & 1200 & $83.3+16.7$ & 50 & 2000 & 5 & 25 & 10,000 \\
\hline $\begin{array}{l}\text { 1:10 Dilution } \\
\text { (MNCs: 600) }\end{array}$ & 1200 & $8.3+91.7$ & 50 & 200 & 5 & 25 & 1000 \\
\hline $\begin{array}{l}\text { 1:100 Dilution } \\
\text { (MNCs: 60) }\end{array}$ & 120 & $8.3+91.7$ & 50 & 20 & 5 & 25 & 100 \\
\hline $\begin{array}{r}\text { To prepare the } \\
\text { from the }\end{array}$ & $\begin{array}{l}\text { al gene co } \\
\text { nple with t }\end{array}$ & $\begin{array}{l}\text { umber with } 10 \\
0 \text { copies (obtai }\end{array}$ & $\begin{array}{l}\text { pies, we made } \\
\text { after DNA e }\end{array}$ & $\begin{array}{l}10 \text { dilution } \\
\text { ction) }\end{array}$ & 5 & 25 & 10 \\
\hline
\end{tabular}

Table 5. Performance evaluation of noninvasive fetal sex determination test using diagnostic test parameters.

\begin{tabular}{ll}
\hline Diagnostic test parameters & Fetal sex by noninvasive prenatal diagnosis \\
\hline Sensitivity & $100 \%(82.35 \%$ to $100.00 \%) *$ \\
Specificity & $100 \%(83.89 \%$ to $100.00 \%)$ \\
Positive predictive value & $100 \%$ \\
Negative predictive value & $100 \%$ \\
Accuracy & $100 \%(91.19 \%$ to $100.00 \%)$ \\
\hline *95\% Confidence Interval. &
\end{tabular}


Table 6. Results of calculation of PCR efficiency, correlation coefficient (R2) and curve slope with mean Ct value for each of the target genes (except beta-actin) in the samples with specified copy number.

\begin{tabular}{llllllll}
\hline Gene name & Efficiency & $\mathbf{R}^{\mathbf{2}}$ value & Slope & $\begin{array}{l}\text { Mean Ct value } \\
\text { for 10,000 copies }\end{array}$ & $\begin{array}{l}\text { Mean Ct value } \\
\text { for 1000 copies }\end{array}$ & $\begin{array}{l}\text { Mean Ct value } \\
\text { for 100 copies }\end{array}$ & $\begin{array}{l}\text { Mean Ct value } \\
\text { for 10 copies }\end{array}$ \\
\hline SRY & 1.82 & 0.99 & -3.85 & 29.55 & 33.88 & 37.26 & Neg \\
\hline Beta-globin & 1.8 & 0.92 & -3.91 & 28.55 & 32.53 & 36.38 & 38.20 \\
\hline RASSF1A & 1.73 & 0.98 & -4.21 & 34.01 & 38.81 & 42.31 & $\mathrm{Neg}$ \\
\hline
\end{tabular}

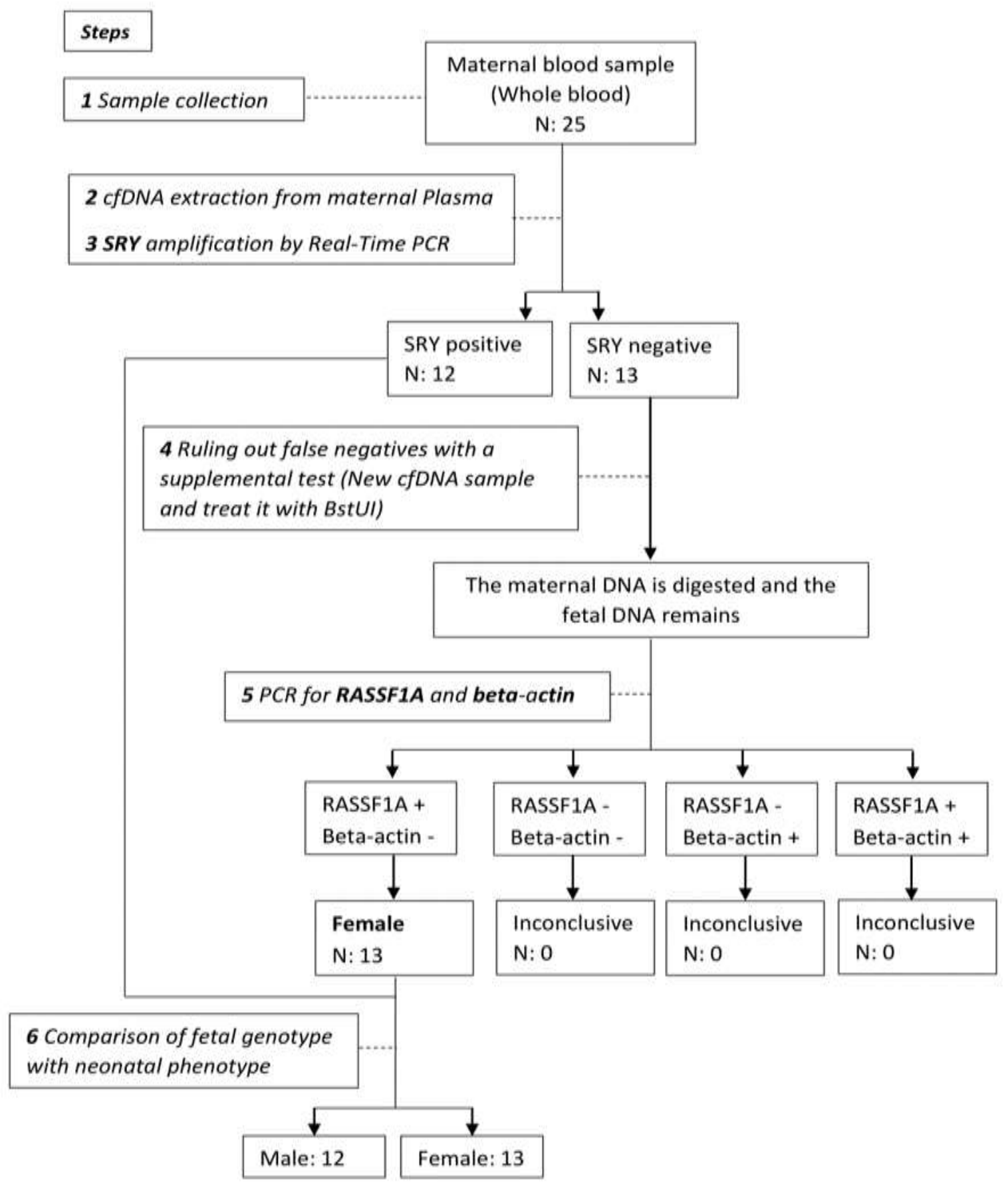

Fig. 1. Flowchart of the steps and results of noninvasive fetal sex determination. 


\section{Discussion}

Non-invasive fetal sex determination is nowadays performed as a NIPT test to timely identify and manage high-risk cases of sexlinked genetic diseases. The present study was conducted in this regard and the results show the high accuracy of the method used for this number of samples.

One of the important issues regarding fetal sex determination by the molecular method is the prevention of false and invalid results, especially false-negative results. The major cause of the false-negative results is the low cffDNA level in the plasma sample which is most often observed when sampling has been done in the early weeks of pregnancy $(20,21)$.

Researchers generally recommend using more plasma volume for DNA extraction (depending on the ability of the extraction kit), reducing the volume of the final buffer elution, and using more DNA template for PCR to improve assays (13). In the present study, our approach to managing this challenge was the use of lower elution buffer volume $(35 \mu \mathrm{l})$ and higher DNA sample volume in PCR reaction $(6.5 \mu \mathrm{l})$ for cases under 14 weeks of gestation. Since these two simple steps had a positive effect on cffDNA concentration, no false-negative results were found, and all samples were genotyped correctly. However, the number of these samples (the first trimester) was not large enough to state with certainty that this strategy is appropriate for cases in the early weeks of pregnancy. In general, and based on the results of other studies, to reduce false-negative results, performing this test from week 7 onwards is recommended and there's also no need to do it in the earlier weeks $(5,22)$.

In cases where SRY was negative, the use of RASSF1A as a sex-independent universal fetal marker played an important role in ruling out false-negatives. According to the results of the 13 cases for whom the RASSF1A assay was carried out, RASSF1A can be introduced as an appropriate and beneficial marker for internal control in fetal sex determination, though studies with larger sample sizes are required to verify its accuracy. Since RASSF1A is a promoter of a tumor suppressor gene and its methylation may be altered in cancer patients, in order to prevent false-positive results in the RASSF1A assay, a history of cancer in the women studied was also taken into account (14, 23).

The relationship between the time of plasma separation and the amount of cffDNA is of paramount importance, according to which generally the sooner plasma separation is performed (in the early hours of sampling), the higher the relative quantity of cffDNA (relative to maternal DNA released from white Blood cells), and the better its quality (24-26). Plasma isolation was performed with a delay after 48 hours of storage at $4{ }^{\circ} \mathrm{C}$ in four cases. However, the results of fetal genotype and neonatal phenotype (gender) were totally consistent and no errors were observed. Jensen and colleagues (2019) also found in a study on 50 cases of pregnant women that delaying plasma separation up to 72 hours did not significantly affect the amount of cffDNA in the maternal plasma. They reported a relatively short time difference (1 to 72 hours) as a possible cause of this outcome (27). However, further studies with a larger sample size are recommended to confirm this.

Absolute quantitative analysis in this study was performed using an in-house method, and the results were acceptable. Estimates of the total cfDNA (beta-globin) and cffDNA (SRY or RASSF1A) copy numbers of the analyzed samples can be obtained using the mean $\mathrm{Ct}$ values obtained from PCR for each copy number (according to Table 6) and their standard curves. Although this in-house method may not have the efficacy of commercial standard-based methods, it can partly meet the purposes of quantifying target genes, in the absence of commercial standard reagents and to reduce costs.

Although the main purpose of this study was to establish and evaluate the diagnostic accuracy of noninvasive fetal sex determination in the first and second trimesters of pregnancy, performing this test in the early weeks for identifying and managing sex-linked diseases is of greater importance and clinical efficacy for 
the individual at-risk (1). Therefore, the main limitation of the present study is the small sample size of the first trimester, which can be addressed in future studies to increase the power of the study and its clinical use.

Non-invasive fetal sex determination testing using the strategy used in this study can be performed with high accuracy from week 7 onwards and can be a suitable alternative to traditional and invasive methods of fetal sex determination in the management of sex-linked genetic diseases.

\section{References}

1. Hill M, Lewis C, Jenkins L, Allen S, Elles RG, Chitty LS. Implementing noninvasive prenatal fetal sex determination using cell-free fetal DNA in the United Kingdom. Expert Opin Biol Ther. 2012;12(sup1):S119-26.

2. Azab NI, Salim RF, Farag MAH. Comparative value of real time and conventional PCR in antenatal gender determination. Bulletin of Egyptian Society for Physiological Sciences. 2016;36(1):30-41.

3. Honda H, Miharu N, Ohashi Y, Samura O, Kinutani M, Hara $\mathrm{T}$, et al. Fetal gender determination in early pregnancy through qualitative and quantitative analysis of fetal DNA in maternal serum. Hum Genet. 2002;110(1):75-9.

4. Rijnders RJ, van der Schoot CE, Bossers B, de Vroede MA, Christiaens GC. Fetal sex determination from maternal plasma in pregnancies at risk for congenital adrenal hyperplasia. Obstet Gynecol. 2001;98(3):374-8.

5. Hill M, Finning K, Martin P, Hogg J, Meaney C, Norbury G, et al. Non-invasive prenatal determination of fetal sex: translating research into clinical practice. Clin Genet. 2011;80(1):68-75.

6. Mujezinovic F, Alfirevic Z. Procedure-related complications of amniocentesis and chorionic villous sampling: a systematic review. Obstet Gynecol. 2007;110(3):687-94.

7. Lo YD, Hjelm NM, Fidler C, Sargent IL, Murphy $\mathrm{MF}$, Chamberlain PF, et al. Prenatal diagnosis of fetal $\mathrm{RhD}$ status by molecular analysis of maternal plasma. N Engl J Med. 1998;339(24):1734-8.

8. Lo YD, Corbetta N, Chamberlain PF, Rai V, Sargent IL, Redman CW, et al. Presence of fetal

\section{Acknowledgements}

This article has been extracted from a doctoral dissertation and was financially supported by the High Institute for Research and Education in Transfusion Medicine, Tehran, Iran. We sincerely thank all the volunteers who have contributed to this project. We would also like to thank Ms. Fatemeh Pandeh, Ms. Jamileh Khorrami Rad, and Ms. Fereshteh Ramzi, the nurses who assisted us in sampling the volunteers.

DNA in maternal plasma and serum. Lancet. 1997;350(9076):485-7.

9. Rijnders R, Van Der Luijt R, Peters E, Goeree J, Van Der Schoot C, Ploos Van Amstel J, et al. Earliest gestational age for fetal sexing in cell-free maternal plasma. Prenat Diagn. 2003;23(13):1042-4.

10. Alberry M, Maddocks D, Jones M, Abdel Hadi M, Abdel-Fattah S, Avent N, et al. Free fetal DNA in maternal plasma in anembryonic pregnancies: confirmation that the origin is the trophoblast. Prenat Diagn. 2007;27(5):415-8.

11.Faas BH, de Ligt J, Janssen I, Eggink AJ, Wijnberger LD, van Vugt JM, et al. Non-invasive prenatal diagnosis of fetal aneuploidies using massively parallel sequencing-by-ligation and evidence that cell-free fetal DNA in the maternal plasma originates from cytotrophoblastic cells. Expert Opin Biol Ther. 2012;12(suppl 1):S19-26.

12.Azghandi MV, Nasiri M, Shamsa A, Jalali M, Shariati MM. Comparative In silico study of sexdetermining region $\mathrm{Y}$ (SRY) protein sequences involved in sex-determining. Reports of biochemistry molecular biology. 2016;4(2):76-81.

13. Scheffer PG, van der Schoot CE, PageChristiaens GC, Bossers B, van Erp F, de Haas M. Reliability of fetal sex determination using maternal plasma. Obstet Gynecol. 2010;115(1):117-26.

14.Chan KA, Ding C, Gerovassili A, Yeung SW, Chiu RW, Leung TN, et al. Hypermethylated RASSF1A in maternal plasma: a universal fetal DNA marker that improves the reliability of noninvasive prenatal diagnosis. Clin Chem. 2006;52(12):2211-8. 
15. Bellido ML, Radpour R, Lapaire O, Bie ID, Hösli I, Bitzer J, et al. MALDI-TOF mass array analysis of RASSF1A and SERPINB5 methylation patterns in human placenta and plasma. Biol Reprod. 2010;82(4):745-50.

16. Landy H, Keith L. The vanishing twin: a review. Hum Reprod Update. 1998;4(2):177-83.

17. Fernández-Martínez FJ, Galindo A, GarciaBurguillo A, Vargas-Gallego C, Nogués N, Moreno-García $\mathrm{M}$, et al. Noninvasive fetal sex determination in maternal plasma: a prospective feasibility study. Genetics in medicine. 2012;14(1):101-106.

18. Wang X, Wang B, Ye S, Liao Y, Wang L, He Z. Non-invasive foetal RHD genotyping via real-time PCR of foetal DNA from Chinese $\mathrm{RhD}$-negative maternal plasma. Eur J Clin Invest. 2009;39(7):607-17.

19. Orhant L, Anselem O, Fradin M, Becker PH, Beugnet C, Deburgrave N, et al. Droplet digital PCR combined with minisequencing, a new approach to analyze fetal DNA from maternal blood: application to the non-invasive prenatal diagnosis of achondroplasia. Prenat Diagn. 2016;36(5):397-406.

20. Wang E, Batey A, Struble C, Musci T, Song K, Oliphant A. Gestational age and maternal weight effects on fetal cell-free DNA in maternal plasma. Prenat Diagn. 2013;33(7):662-6.

21. Khorshid HRK, Zargari M, Sadeghi MR, Edallatkhah H, Shahhosseiny MH, Kamali K. Early fetal gender determination using real-time PCR analysis of cell-free fetal DNA during 6th-10th weeks of gestation. Acta Med Iran. 2013;51(1):209-14.
22. Bustamante-Aragones A, Rodriguez de Alba M, Gonzalez-Gonzalez C, Trujillo-Tiebas M, Diego-Alvarez D, Vallespin E, et al. Foetal sex determination in maternal blood from the seventh week of gestation and its role in diagnosing haemophilia in the foetuses of female carriers. Haemophilia. 2008;14(3):593-8.

23. Chan KA, Lai PB, Mok TS, Chan HL, Ding C, Yeung S, et al. Quantitative analysis of circulating methylated DNA as a biomarker for hepatocellular carcinoma. Clin Chem. 2008;54(9):1528-36.

24. Chiu RW, Poon LL, Lau TK, Leung TN, Wong EM, Lo YD. Effects of blood-processing protocols on fetal and total DNA quantification in maternal plasma. Clinical chemistry. 2001;47(9):1607-1613.

25. Angert RM, LeShane ES, Lo YD, Chan LY, Delli-Bovi LC, Bianchi DW. Fetal cell-free plasma DNA concentrations in maternal blood are stable 24 hours after collection: analysis of first-and thirdtrimester samples. Clin chem. 2003;49(1):195-8.

26. Fernando M, Chen K, Norton S, Krzyzanowski G, Bourne D, Hunsley B, et al. A new methodology to preserve the original proportion and integrity of cell-free fetal DNA in maternal plasma during sample processing and storage. Prenat Diagn. 2010;30(5):418-24.

27. Jensen MP, Damkjaer MB, Clausen FB, Ali HA, Hare KJ, Dziegiel MH, et al. Targeted Rhesus immunoglobulin for RhD-negative women undergoing an induced abortion: A clinical pilot study. Acta Obstet Gynecol Scand. 2019;98(9):1164-1171. 